\title{
Improving Quality Education through Better Working Conditions of Academic Institutes
}

\author{
Teguh Budiharso \\ 1State Islamic Institute (IAIN) of Surakarta, Indonesia \\ Bulent Tarman 1 \\ Independent Researcher, Turkey
}

\begin{abstract}
For better quality of education, working conditions of the educational institutes is very important. In addition, faculty retention and employability are very crucial in this regard. In the current study, the aim of the author is to study the impact of working conditions on quality education in Indonesia in the presence of mediation of faculty retention and employability. For this purpose, data was collected from 293 faculty members of the educational institutes of Indonesia. To analyze the gathered data, confirmatory factor analysis and structural equation modeling approaches have been used. The results of data analysis have shown that the impact of working condition on quality education is insignificant but the mediating role of employability and faculty retention are significant in this regard. In the last section of the study, several theoretical, practical and policy making implications have been discussed by the author. In addition, some limitations and future research indications have also been described.
\end{abstract}

Keywords: employability, faculty retention, quality education, working conditions.

\section{Introduction}

In countries the development and growth is significantlycatalyzed by the factors such as working condition of an organization, mediating role of faculty retention and employability on the quality of education under the influence of working conditions. Qualityeducation is the critical factor for the professional development of a nation that plays a vital role in the development of country and enhance global competitiveness (Aman, 2009; Carcolini, 2017; Collins, 1990; Tarman, 2016; 2017). Indonesia is a well-known country with a significant number of natural resources, but still Indonesia is facing problems inthe education department due unemployment and some issues related to faulty attrition. Indonesia youth literacy rate was 99.7\% in 2016 that is comparatively higher than the other Southeast Asian nation, as the literacy rate of India and Pakistan is $86 \%$ and $72 \%$ (Barken et al., 2018; World Bank, 2018). As Ashraf (2019) said that the major concern that demands for more attention area is not the literacyrate, it is the quality of education. Over the past few decades, the country has made great strides to improve access to education, particularly at the secondary level but still facing the problem of quality of education due to incompatibility between working conditions, education quality and faculty retention (Ashraf, 2019). Turnover negatively affects the students and quality of 
education. Faculty retention is the primary worldwide issue that is mainly experienced by Indonesia, as in Indonesia Faculty turnover rate is most crucial factor than other Southeast Asian nations due to inadequate working conditions of academic institutes. This issue causes inadequate international standardize assessments of students relative to the other countries (Mbiti, 2016).

Quality education is directly or indirectly influenced by the Employability rate and quality of outcomes that are achieved through this (Fomunyam, 2018). Employability positively influences the quality of education by developing the skills and competencies that help students at the workplace. The employability rate in Indonesia is relatively low. According to the World Bank (2018) data, the unemployment rate of Indonesia in 2017 was 4.2\%, that shows the unemployment rate in Indonesia is still much higher than developed countries such as Japan, with only a $2.8 \%$ unemployment rate (Fomunyam, 2018). In the early 1980s, Indonesian education system made remarkable performance compared to lower-middle-income countries, andIndonesia ranked only 69th (on the WEF capital index 2015). This can be due to the poor working conditions in academic institutes and its various relevant factors.

Faculty retention positively influences the quality of education in an institute. From the first decade of the 2000s, faculty retention is the primary concern of all the good institute that is faculty should not be bound to follow the same typical rules (Gajić, 2012; Graffam, Shinkfield \& Hardcastle, 2008). For the betterment of students, faculty is encouraged to adopt modern ways to train the young generation, especially in tertiary level education. Therefore, it is essential to address this problem because this issue is necessary for the secondary level of knowledge in developing countries like Indonesia; in fact, Indonesia still faces challenges in the secondary level of education (Fomunyam, 2018). The level of tertiary education in Indonesia is quite compromising as the quality of education is facing lots of challenges, this can be because of poor working conditions in academic institutes and various faculty related problems (Ashraf, 2019; Nawaz, Afzal \& Shehzadi, 2013). Indonesia is not the only country that is addressing the issues of poor working conditions or issues of quality education, as in 2018 the unemployment rate of India and Germany was $6 \%$ and $3.3 \%$, respectively and in Indonesia, the unemployment rate was $5.34 \%$ in 2018, and was 5.50\% in 2017 (Mbiti, 2016).

Solution of this issue is the critical priority of the Indonesian government. If proper steps would not be taken, then the performance of the educational institutions will further decline. In return, when students of these institutes will go in the market, then they will not be able to excel in their fields that will indirectly affect the developing growth of a country. There have been several studies conducted on the quality of education in Indonesia, but none of these studies discusses the influence of particular factors like working conditions, Faculty retention, and employability on the quality education of secondary level in Indonesia. Gora, Ștefan, Popa, and Albu (2019) and Ashraf (2019) presented this kind of studies, but none of them took both employability and faculty retention as mediators. Now this study plays an essential contribution filling the research gap and examining the relationships between the working conditions and quality of education. It also examines the effect of faculty retention and employability on the quality of education as a mediating variable. Further sections of research papers are critical Literature review regarding these parameters, methods, result and discussion, conclusion and implication.

\section{Research Questions}

The current study explored the impact of working condition of academic institute towards the quality of education in higher education in Indonesia. Specifically, it aimed to provide answers to the following research questions: 
1) Is there any significant impact between working condition towards quality education in Indonesia?

2) Is there any significant mediation between faculty retention towards working conditions and quality education in Indonesia?

3) Is there any significant mediation role between working condition and quality education in Indonesia?

\section{Literature Review}

\section{Quality}

Literature defines the term quality in various ways. Online dictionary defines quality as a tool to compare of any good or service of a property. In a modern definition, quality derives from fitness for intended use that indicates "meeting or exceeding customer expectation". Quality has two meaning: a product or service to satisfy the needs, and a product or service that is free of deficiencies. Mari \& Bjørn (2018) summarize the definition of quality as: (1) the degree to satisfy an attribute or requirement of an entity, e.g. process, product, or service; (2) comparing a set of inherent characteristics with a set of requirements; and (3) the degree to which a set of inherent characteristics fulfils requirements. To sum up, Shah, Nair, Said \& Wilson (2011) define quality as an outcome to which a goods or service is provided to satisfy a customer or stakeholders. The core of quality is the customer requirements.

Quality concepts in higher education pertains to efficiency, high standards, excellence, value for money, fitness for purpose and/or customer focused (Watty, 2006:293). The fitness for purpose represents the mission, goals, objectives, specifications to which the organization operates the procedures proper to the specified purposes and evidence to achieve the specified purposes (Akareem \& Hossain, 2016; Dinh, 2019; Grewal et al., 2019).

Harvey \& Green (1993) indicate the quality as (1) an exceptional that meets a high standard, (2) a perfection or consistency that is done correctly and consistently to the standard, (3) fitness for purpose that is proper to quality assurance goal, (4) the value for money that assures stakeholders receive high value for their investment, (5) a transformation that ensures students are empowered genuinely through learning.

Reform in higher education institutions under takes activities as an impact of globalization, accountability, supply and demand issues, competition, and technology as the quality assurance (Tadeu et al., 2019; Volegzhanina et al., 2017) "Quality assurance means the procedures, processes and systems used by the higher education institution to manage and improve the quality of its education and other activities". Quality assurance enable students to achieve the set standards (The National Education Association (NEA), 2006).

As Lenn (2004) suggests approaches in quality assurance includes accreditation, measurement, audit of academic and external examination whose purpose is the assessment or enhancement to guides further improvement of the program. There are four aspects of the quality program as suggested by Arcaro (1995:1), they are: willing to change, proper knowledge towards condition of the program, a clear vision of the future and application of the quality vision. Specifically, NEA (2006) divides issues on quality educational into: (1) shared understanding and commitment to high goals, (2) open communication and collaborative problem solving, (3) continuous assessment for teaching and learning, (4) personal and professional learning, (5) resources to support teaching and learning, and (6) curriculum and instruction. Each issue is developed through a benchmarking. Sallis (2002:151-159) has identified the contribution of the 
benchmarking as follows: (1) effective learning and teaching (20\%), (2) leadership (15\%), (3) Staff (15\%), (4) students (15\%), (5) standards (10\%), (6) organization (5\%), (7) physical environment and resources (5\%), (8) external relations (5\%), (9) access (5\%), and (10) service to customers $(5 \%)$.

We argue in this paper that quality education is represented in the management process that includes the quality assurance. The quality of education is indicated in the better working conditions of employment of the academic staffs.

\section{Theory of Maslow's Hierarchy of Needs}

Abraham Maslow introduced his approach that is the hierarchy of five basic human needs in 1943, that states that people are motivated by five essential needs (Hale, Ricotta, Freed, Smith \& Huang, 2019). At the core of the theory, there is a goal to develop a compassionate and effective working condition to inspire the employability to hold in the organization (Shahrawat \& Shahrawat, 2017). According to this theory, there are several types of needs, for example, the most basic need in the hierarchy is physiological needs that categorize as food, water, warmth and rest, etc. (Hale et al., 2019). The next to physiological need is safety and it can be categorized as security, employment, freedom from fear, and health protection (Hale et al., 2019). After the fulfillment of safety and physiological needs, there comes the third level of human needs that is social needs, for example, friendships, love and belongings (Thalib, 2016; Hatta \& Rini, 2018). The next level needs are esteem needs, for example, achievement, dignity, self-respect, reputation, status, etc. (Lester, 2013). The last and higher level of needs is self-actualization and in this stage, a person is doing his best in the context in which he is supposed to excel, or in other words, he is exploring himself in the right direction (Lester, 2013).

This theory of needs can be applied in working condition to motivate the employability in an organization. For example, if an employee works properly in an organization, then he can meet his physiological needs through his salary. In return, the organization facilitates their employees by providing a safe environment and secure job that somehow meets with the condition of safety needs. Social needs are relatable with close supervision. The appreciation due to the individual's professional behavior towards his job fulfills the esteem needs. In the end, when someone starts exploring his available opportunities in the right way, he meets the selfactualization need in the right direction (Shahrawat \& Shahrawat, 2017; Woofter, 2019). By improving the working condition in an organization, employability can be motivated, thus in this regard, employees may get motivated to stay in an organization on longer terms if sound working condition is provided (Bouzenita \& Boulanouar, 2016). Based on the theory, to retain excellent faculty in an institute on long terms and to maintain the remarkable record of education requires healthy and encouraging working conditions in an educational institute. Finally, employee retention exerts a positive influence on quality education, too (Jonas, 2016; Robbins et al., 2019).

\section{Working condition and quality education}

As it is stated in above mentioned Maslow's theory, the feasible and secure workplace is the primary concern. Working condition consists of the culture of organization and worker's relation with the organization apart from the elements that covers the working region (Ashraf, 2019). As described by Raziq and Maulabakhsh (2015), Academic institutes are facing different issues due to varying conditions of the environment in Indonesia and in any institute, one of the major problems is to keep the staff for a long time to overcome these issues. Fomunyam (2018) highlighted that for the last few years, the quality of education is a central problem in Indonesia. 
For quality assurance and quality enhancement, there are a vast number of details and hypotheses related to the quality of education. Be that as it may, a little bit of work has been done on this issue in Indonesia (Ashraf, 2019).

Hyršlová, Tomšík and Vnoučková (2017) examined, in many private universities of Indonesia, the basic need for success is to improve the quality of education, which is actually the core demand for competing the high standard universities, so that the quality education must be enhanced (Kehrer, Kradjan, Beardsley \& Zavod, 2008; Kezar, 2005). Consequently, for the assurance of quality of education, the working conditions of the universities should be practiced, along these lines, to have a superior comprehension of the present situation of training (Nelis et al., 2011). It is essential to inspect the improvement of the framework in Indonesia with specific regard for crucial changes or impacts. In Indonesia, various types of policies are needed for the promotion of education as compared to the other countries, and Indonesia accomplished high paces of grade school enlistment beyond the $90 \%$ by the mid-1980s (Mbiti, 2016). Hence, it can be concluded from the above researches, to improve the quality of education in Indonesia, one must improve the working conditions, as the faculty members would like to work in a better workplace and thus, the students can achieve high grades by learning more from their teachers.

Hypothesis 1: Working conditions has a significant impact on quality education in Indonesia.

\section{Working conditions and faculty retention}

Compelling financial and geopolitical circumstances influence the educational system of Indonesia. For a few decades, Indonesians are struggling for their freedom because of their educational system (Juwitasari, 2019) and one of the most critical factors that affect the faculty retention is salary. After surveying 22 countries, it is concluded that ten countries from them stated that an excellent salary package is the main factor that can improve the condition of this profession. Other than salary, another essential factor in Indonesia that influences faculty retention is the working conditions of an institution. According to organizational theory related to working conditions and faculty retention, it can be viewed that the teachers leave their jobs because the terms of institutes are not feasible to work there and not because of the qualities of their pupils.

Barken et al. (2018) stated that most people prefer to work in those organizations that provide a better workplace. Fomunyam (2018) explains that working conditions, for example, factors related to physical and mental conditions inside an organization are significant sparks and where such helpers are less in number, workers will leave their jobs. In Indonesia, teachers have different reasons for turning over their jobs affected by various conditions that are not suitable for them and these reasons include low package of salary, high strength of class, poor states of administration block, significant distance to drive to schools and lack of facilities offered by schools (Moreira-Fontán, García-Señorán, Conde-Rodríguez \& González, 2019; Krynski, 2019). Mampane (2012) suggests that if faculty members have a negative frame of mind or negative impression of their work environment, they would like to miss their classes and commitments, and hence, their performance will be reduced. To make sure progressively aggressive market demand in this manner, it is necessary not to just pull in the talented faculty yet but also to hold them at work for long term (Ashraf, 2019). So, these researches centers around retention of faculty members, which can assume as mediators between working conditions and establishment of better quality of educational institutes. Ashraf (2019) distinguished that a better workplace 
through enthusiastic knowledge can influence the results and performances of any educational sector.

As indicated by Ashraf (2019), achievements of students are also affected by instructive authority and working conditions of academic institutes. Considering this sort of position in the prior studies, it is suggested that faculty members should have enough opportunity to guide their students in a way in which they want to guide and teach them the topics of their interest to increase the chances of success and ultimately enhance the quality of education. So, it is clear that working conditions also affect the quality of education. By improving the conditions of academic institutes, one can ensure the quality of their education. Faculty retention plays the role of mediator between working conditions and quality education (Pasquier \& Nicolescu, 2019).

Hypothesis 2: Faculty retention mediates between working conditions and quality education in Indonesia

\section{Mediating Role of Employability}

Employability plays a mediating role in the working condition and quality education. Working condition directly affects the employability. This education is also correlated with the employee's productivity. Working environment provided by an organization is very important in this regard. The progress of a company mainly depends upon the working conditions. Good working conditions motivate the employees to work hard (Zafar, 2015). Working conditions consist of both physical and non-physical work environment, for example, a company's culture or employee's involvement (Sinaga, Lis \& Razimi, 2019). According to Latip, May, Arif, Kadir, and Kwan (2019), a healthy working condition inspires employees to come at work and retain their excellent performance. This means that employee's commitment towards work can be improved by giving proper privacy and control on work area that indirectly increase the growth rate of a company (Benson \& Dundis, 2003). In an organization, the most valuable assets are the employees.

To hire talented employees and retain them for a long time should be the basic motive of an organization. As Andrianto, Jianhong, Hommey, Damayanti, and Wahyuni (2018) shared their observation that the ability of an organization to retain the talented employees who have a great influence on the success of that organization is mutually favorable. The performance of an employee is a combination of capabilities, businesses, and opportunities that can be judged from their work (Andrianto et al., 2018). Employability has a great influence on working conditions; likewise, the Employability has an impact on the quality of education. In Indonesia, for the past few years, the expansion of secondary schools has been the point of main concern (Azizah, Abraham \& Dhowi, 2017). This positively influences the work environment and income of young educated generation of Indonesia as the quality of education gives surety of a secure future in practical life and permanent job with a handsome wage to a student (Andrianto et al., 2018).

However, during the government of Yudhoyono president 2004-2014, there was a decrease in the unemployment rate in young educated Indonesian by around 5-10\%. For attracting more people toward the tertiary level of education, government expanded the business services of banking and finance. In this way, the government started many new projects for especially poor people, through attractive scholarships in secondary schools (Ginting, Manning \& Taniguchi, 2018). Indonesia made a plan to enroll more people by making attractive policies in the government and private sector. From this discussion, it can be viewed that the primary concern was to improve the quality of education, especially at the tertiary level. Assistance Program for poor students (Bantuan Siswa Miskin) and smart card of Indonesia (Kartu Indonesia 
Pintar) are the plans scheduled under this motive. These are the efforts of Indonesia to improve the quality of education through the productivity of attractive jobs (Benson \& Dundis, 2003).

Hypothesis 3: Employability has a significant mediating role between working conditions and quality education in Indonesia.

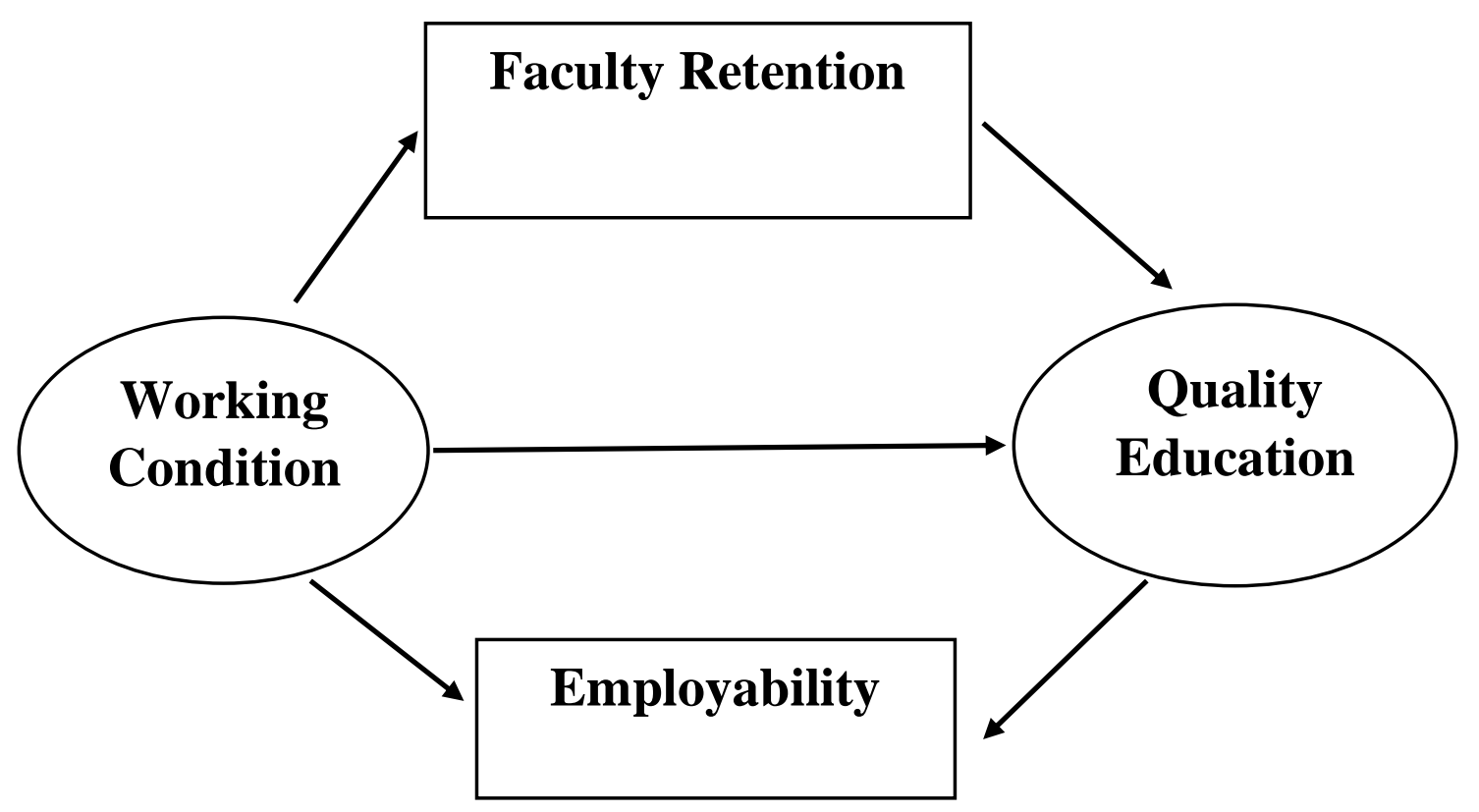

Figure 1. Research Model

\section{Methods}

\section{Design}

The study used a descriptive survey applying the correlational design. The survey component ascertains the prevailing working condition of academic institute and quality of education. AMOS for running the Confirmatory Factor Analysis (CFA) and structure equation modeling were used for the data analysis. In addition, SEM was used for path analysis to show the acceptance or rejection status of hypotheses.

\section{Population and Sampling}

Researcher accompanied this research study for observing the improvement in quality education through the effect of better conditions of academic institutes, in mediating role of faculty retention and employability. The researchers select the population of the Indonesia as population of study because education system in Indonesia is very weak, universities performed many academic misconducts, mismanagement and many irregularities have been observed in the Indonesia education system such as widespread plagiarism, manipulation of administrative records, individual supervisor handle the excessive concentration doctoral supervision. Due to these reasons, it is necessary to take several parameters for controlling the irregularities and for 
improving the quality education. For collecting the data, researcher considered the two universities of the Indonesia, namely the University of Surakarta and the University of Yogyakarta (both are the pseudonyms), Indonesia as these universities offered totally different courses and located in different geographic areas thus, researcher can collect the different perspectives of these universities. Further, sample respondents in this study is teachers and faculty members and they have been selected through purposive sampling technique because they have been participated in the whole education processes, in seminars, course work and in meeting sessions regarding the strategic planning for university that's why it was beneficial to collect data from them. Researchers distribute 350 questionnaires between specific respondents, but only 312 responses have been received and after discarding the invalid and incomplete responses only 293 considered valid responses (see table 1).

\section{Table 1}

\begin{tabular}{llll}
\multicolumn{3}{l}{ Respondents of the research } \\
\hline No & Description & $\mathrm{F}$ & $\%$ \\
& & $\mathrm{~N}=293$ & \\
\hline 1 & Male & 120 & 41.5 \\
2 & Female & 173 & 58.5 \\
3 & Doctor degree & 141 & 48.1 \\
4 & Master's degree & 152 & 51.9 \\
5 & Age 31-40 & 181 & 61.8 \\
6 & Age 41-up & 112 & 38.2 \\
\hline
\end{tabular}

Table 1 suggests that the 293 participants, $41.5 \%$ males and $58.4 \%$ females, were selected for this study. The sample is dominated by highly educated respondents with $48.1 \%$ having postgraduate degrees and $51.9 \%$ having master's degrees. The prominent age group in the sample was $31-40$ with $61.8 \%$ respondents. Thus, the sample is mature enough, in terms of both age and education, to understand the complexities of this study.

\section{Data Collection Procedures}

Structured questionnaire has been used in this research study for data collection because survey-based questionnaire enables the researcher to collect the primary, quantitative and objective data from large number of respondents. Questionnaire has been structured in closed ended questions, in which researcher asked the demographic questions and variable scale items. Researcher ensured that language of questionnaire must be in accordance to the native language of Indonesia, so that they can easily solve it. Later on, researcher can use the back-translation method for again translating the questionnaire into English language. Further, researcher conduct the pilot study for verifying that survey questionnaire was understandable by respondents or not. After finalizing the questionnaire, researcher administered it through self-administering technique because some respondents were unable to understand the specific terms that's why researcher self-visit the respondents for rectifying the queries.

\section{Measures}

For the measurement of independent, dependent and mediating variables measurement, researcher has adapted the measurement items from various authors work in previous literature, as these measures were more reliable and authentic. For quality education, 8 measurement items 
have been adapted from research work of Biggs \& Watkins (1995), researcher adapts 4 survey items for working condition, from research study of Edgar \& Geare (2005). Further, faculty retention has been measured through 6 survey items, which have been taken from work of Milman \& Dickson (2014) and researcher measured the employability variable through 2 survey items from Pasquier \& Nicolescu (2019) and (Huiszoon, Martinent \& Bodet, 2018). All these measurement items have been measured through 5-point Likert scale, in which responses of respondents have been recorded in range from 1 (strongly disagree) to 5 (strongly agree). The instrument was revalidating in terms of language of presentation, clarity, and relevance of the items to the variable. The instrument was trial-tested on 10 teachers and responses of the teachers were analysed using Cronbach alpha and the reliability coefficient of 0.78 was obtained.

\section{Data Analysis}

For data analysis, researcher used the two software such as SPSS and AMOS, different tests have been run under them for verifying the reliability, validity and checking the structural model. For reliability researcher accompanied SPSS and for assessing the reliability researcher used two criteria such as Cronbach's alpha and composite reliability, both of them must have the value greater than 0.70 because it ensured the items reliability and internal consistency respectively. Further, researcher used the AMOS for running the two analyses such as confirmatory factor analysis and structure equation modeling. CFA has been used for assessing the discriminant validity, convergent validity of the measures used in proposed study and for model fitness. On the other hand, SEM has been used for path analysis, which reports the acceptance or rejection status of hypotheses.

\section{Results and Discussion}

This section presents the results of the study that show two phases of data analysis. In the first phase, descriptive analysis through frequency and percentage was used to describe the data. In the second phase we went through CFA and structural equation modeling approaches. The results start from the presentation of Table 2 .

Table 2

Descriptive Statistics

\begin{tabular}{|c|c|c|c|c|c|c|c|c|}
\hline & \multirow{2}{*}{$\begin{array}{c}\mathrm{N} \\
\text { Statistic }\end{array}$} & \multirow{2}{*}{$\begin{array}{c}\text { Minimum } \\
\text { Statistic }\end{array}$} & \multirow{2}{*}{$\begin{array}{c}\text { Maximum } \\
\text { Statistic }\end{array}$} & \multirow{2}{*}{$\begin{array}{c}\text { Mean } \\
\text { Statistic }\end{array}$} & \multirow{2}{*}{$\begin{array}{c}\text { SD } \\
\text { Statistic }\end{array}$} & \multicolumn{2}{|c|}{ Skewness } \\
\hline & & & & & & & Statistic & SE \\
\hline FacReten & & 293 & 1.00 & 5.00 & 3.6092 & 1.06496 & -.914 & .142 \\
\hline WorkCond & & 293 & 1.00 & 5.00 & 3.5836 & 1.11853 & -.803 & .142 \\
\hline EmpAbility & & 293 & 1.00 & 5.00 & 3.5836 & 1.13958 & -.814 & .142 \\
\hline QuaEduc & & 293 & 1.00 & 5.00 & 3.4625 & 1.11294 & -.570 & .142 \\
\hline $\begin{array}{l}\text { Valid } \\
\text { (listwise) }\end{array}$ & $\mathrm{N}$ & 293 & & & & & & \\
\hline
\end{tabular}

Table 2 shows the descriptive statistics for this study. There are no outliers in the data which is proven by the minimum and maximum statistics. The mean statistics show an average of 3.5 , depicting that the respondents revolved around neutrality to agreement about the statements 
given in the questionnaire. The normality of the data has been proven by skewness testing, as all the results lie in between the threshold range of -1 to +1 .

\section{Table 3}

KMO and Bartlett's Test

\begin{tabular}{llc}
\hline \multicolumn{2}{l}{ Kaiser-Meyer-Olkin Measure of Sampling Adequacy. } & .913 \\
\hline Bartlett's Test of Sphericity & Approx. Chi-Square & 6642.133 \\
\cline { 2 - 3 } & Df & 190 \\
\cline { 2 - 3 } & Sig. & .000 \\
\hline
\end{tabular}

For testing validity of sample size, KMO and Bartlett's Test are used in this study and the results have been presented in Table 3 . The result is 0.913 , confirming adequacy of size, since it lies between threshold range of 0.8 and 1 .

Table 3 is summarizing the results for the rooted component matrix, which is a part of CFA. This is a mechanism for testing data accuracy and validity. Results show that all the components carry factor loading greater than 0.7 and no issue of cross loading is seen in any variable.

\section{Table 4}

Rotated Component Matrix

\begin{tabular}{|c|c|c|c|c|}
\hline & & & & \\
\hline & 1 & 2 & 3 & 4 \\
\hline FR1 & & .725 & & \\
\hline FR2 & & .783 & & \\
\hline FR3 & & .852 & & \\
\hline FR4 & & .848 & & \\
\hline FR5 & & .833 & & \\
\hline FR6 & & .807 & & \\
\hline WC1 & & & .817 & \\
\hline WC2 & & & .856 & \\
\hline WC3 & & & .853 & \\
\hline WC4 & & & .834 & \\
\hline EA1 & & & & .824 \\
\hline EA2 & & & & .854 \\
\hline QE1 & .849 & & & \\
\hline QE2 & .872 & & & \\
\hline QE3 & .875 & & & \\
\hline QE4 & .887 & & & \\
\hline QE5 & .889 & & & \\
\hline QE6 & .887 & & & \\
\hline QE7 & .870 & & & \\
\hline QE8 & .836 & & & \\
\hline
\end{tabular}




\section{Table 5}

Convergent and Discriminant Validity

\begin{tabular}{lcccccccc} 
& CR & AVE & MSV & MaxR(H) & EA & FR & QE & WC \\
EA & 0.896 & 0.813 & 0.373 & 0.904 & $\mathbf{0 . 9 0 1}$ & & & \\
FR & 0.944 & 0.736 & 0.394 & 0.965 & 0.544 & $\mathbf{0 . 8 5 8}$ & & \\
QE & 0.945 & 0.775 & 0.260 & 0.984 & 0.464 & 0.510 & $\mathbf{0 . 8 8 0}$ & \\
WC & 0.937 & 0.787 & 0.394 & 0.987 & 0.611 & 0.628 & 0.398 & $\mathbf{0 . 8 8 7}$ \\
\hline
\end{tabular}

Table 5 is a depiction of convergent and discriminant validity test results. Convergent validity is indicated by $\mathrm{CR}$ and AVE that have low threshold values of 0.7 and 0.5 respectively, which is confirmed by the results, showing that there is convergent validity. Results are given in the diagonal portion of table show discriminant validity results. Each variable is more associated with itself as each of the values is larger than the values preceded by them. This is a confirmation that discriminant validity exists in the data taken for this research.

\section{Table 6}

Confirmatory Factors Analysis

\begin{tabular}{lcc}
\hline Indicators & Threshold range & Current values \\
\hline CMIN/DF & Less or equal 3 & 2.655 \\
GFI & Equal or greater .80 & .875 \\
CFI & Equal or greater 90 & .960 \\
IFI & Equal or greater .90 & .960 \\
RMSEA & Less or equal .08 & .075 \\
\hline
\end{tabular}

Table 6 shows results for confirmatory factor analysis that is conducted to show fitness of model. The indicators included in the table, CMIN, GFI, CFI, IFI and RMSEA all need to have values according to the described thresholds. Fitness of the model is confirmed by the results since all the values are within the threshold mentioned in the table.

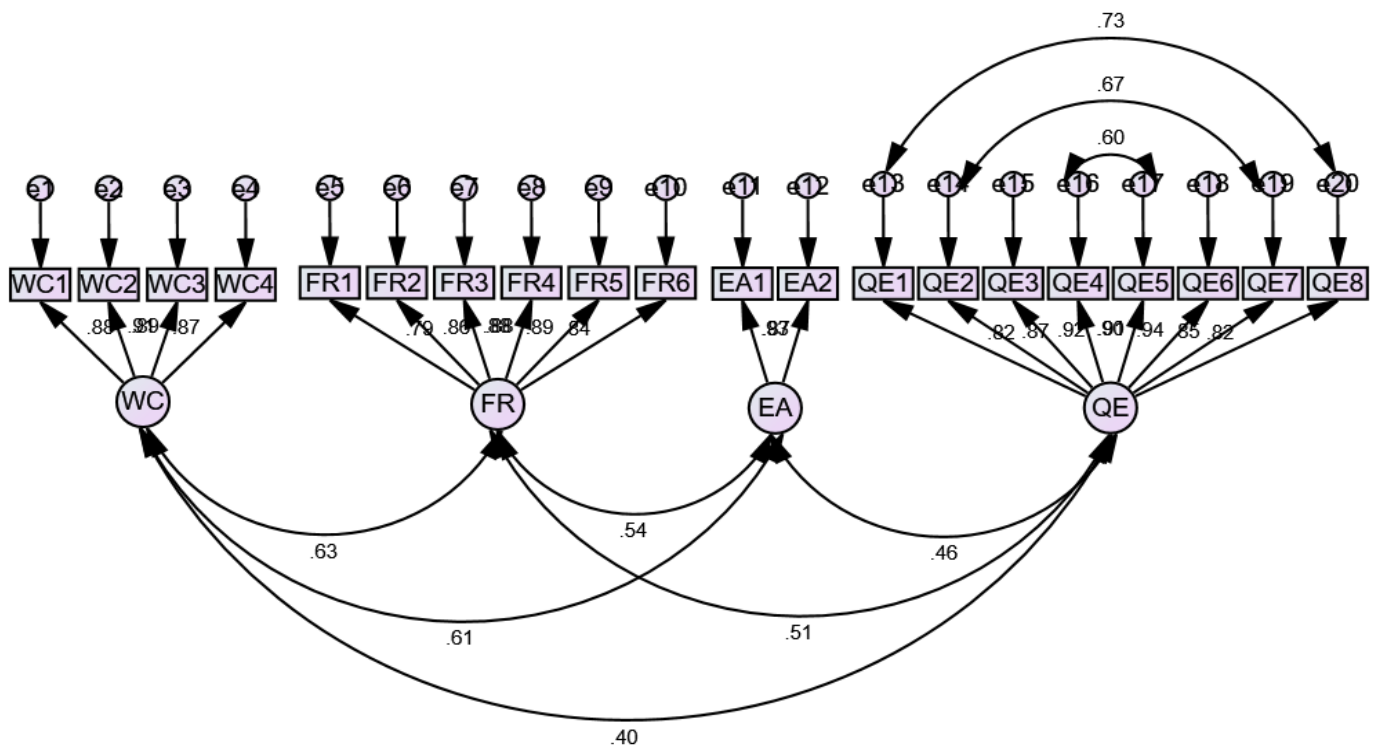

Figure 2. CFA 


\section{Table 7}

Structural Equation Modeling

\begin{tabular}{lccc}
\hline Total Effect & WorkCond & EmpAbility & FacReten \\
\hline EmpAbility & $.566 * * *$ & .000 & .000 \\
FacReten & $.602 * * *$ & .000 & .000 \\
QuaEduc & $.389 * * *$ & $.244 * *$ & $.357 * * *$ \\
Direct effect & WorkCond & EmpAbility & FacReten \\
EmpAbility & $.566 * * *$ & .000 & .000 \\
FacReten & $.602 * * *$ & .000 & .000 \\
QuaEduc & .036 & $.244 * *$ & $.357 * * *$ \\
Indirect effect & WorkCond & EmpAbility & FacReten \\
EmpAbility & .000 & .000 & .000 \\
FacReten & .000 & .000 & .000 \\
QuaEduc & $.353 * * *$ & .000 & .000 \\
\hline
\end{tabular}

\section{Hypothesis Testing}

The table 7 summarizes the hypothesis testing, done through structural equation modeling. The results clearly show that there is no direct significant effect between work conditions and quality of education. However, the indirect effect through mediators is significant and positive, showing increase of $35.3 \%$ in quality of education. By increasing one unit of work condition, $56.6 \%$ increase is seen in the employability while $60.2 \%$ increase is seen in faculty retention. Similarly, quality of education is increased by $24.4 \%$ and $35.7 \%$ by increasing one unit of employability and faculty retention respectively. The results prove that a full mediation exists between these variables. We can therefore summarize that there is no significant direct impact of improving work conditions on the quality of education in academic institutes, but indirectly, mediator roles of employability and faculty retention, cause a significant and positive increase in the education quality.

To investigate the impact of the working conditions of academic institutes on the quality of education in a country was the basic motive behind this research. The author of this research formulized three hypotheses that were tested using various analytical techniques. The first hypothesis mentioned that the working conditions of academic institute have a significant impact on the quality of education in that institute. According to the above mentioned results this hypothesis was rejected. There was no direct significant effect of the working conditions on the education quality. Similar results were discussed in previous studies (Leithwood, Harris \& Hopkins, 2008; Siddique, Aslam, Khan \& Fatima, 2011). The second hypothesis mentions that faculty retention mediates between working conditions and quality of education, while the third hypothesis mentions that employability levels mediate between working conditions and quality of education. Both these hypotheses lay the ground for generating an indirect effect of working conditions over quality of education. The analysis and results section shows results for both of these hypotheses to be accepted with positive and significant effects. Similar results were presented in a number of studies (Bibi, Pangil, Johari \& Ahmad, 2017; Woya, 2019). These results for mediating roles of employability and faculty retention between working conditions of academic institutes and the quality of education show confirm that a significant indirect and positive effect exists between them. 


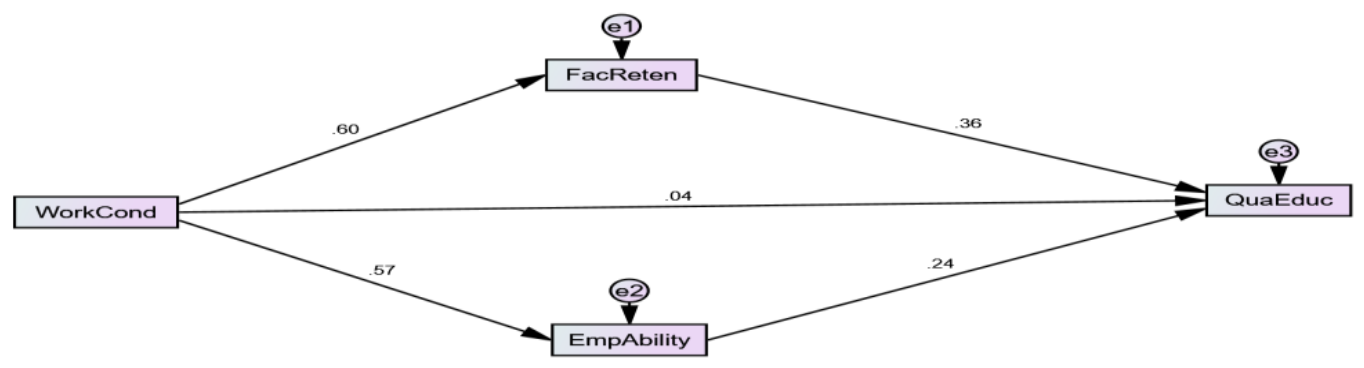

Figure 3. SEM

\section{Conclusion}

This study has examined the effect of working conditions on the quality education. In summary, this study reveals that the working condition of academic institutes is a factor that affects quality of education to a great extent. More specific findings of this study indicate that the teachers and principals are the major controlling factors in an institute and are responsible for the provision of education to the students. If the working conditions are not kept positive, these key employees become distressed and this distress is translated into degraded education quality. If the working conditions are healthy, the employee retention is increased and better employability levels are seen. These positive effects were seen on the education quality. Several implications on policies, theory and practice applications are given by the authors in the next section.

\section{Implications}

Since this study deals with improving the education quality by usage of good working conditions for the faculty, it has serious theoretical, practical and policy-making implications. Peer researchers can benefit from the relational literature review to understand how the selected variables affect the quality of education. The officials of educational institutes can use this study as a guideline for setting of employability levels while hiring new teaching staff and for improving the levels of teacher retention at their organizations. In addition, the government can use this study to design policies that can help to improve the working conditions of academic institutes in their jurisdiction.

\section{Limitations and future implications}

In this research, the author analyzed the factors that can help to improve quality of education in Indonesia only; for future, similar variables must be tested on a larger scale data, so that more generalized results may be generated. In addition to the studied variables, retention and employability, there are numerous factors, like education level of teachers, teacher politeness levels and the level of innovation used in teaching, that affect the working conditions of an 
academic institute. These variables must be considered in the future researches so that the research presents on the topic of quality of education can be improved.

\section{References}

Akareem, S. H \& Hossain, S, S. (2016). Determinants of education quality: what makes students' perception different?, Open Review of Educational Research, 3(1), 52-67. DOI: 10.1080/23265507.2016.1155167

Aman, R. R. (2009). Improving student satisfaction and retention with online instruction through systematic faculty peer review of courses. Retrieved from https://ir.library.oregonstate.edu/concern/graduate_thesis_or_dissertations/6q182q48q

Andrianto, S., Jianhong, M., Hommey, C., Damayanti, D., \& Wahyuni, H. (2018). Re-entry Adjustment and Job Embeddedness: The Mediating Role of Professional Identity in Indonesian Returnees. Frontiers in psychology, 9, 1-6.

Arcaro,S.J. (1995). Quality in Education: An Implementation Handbook. Alih bahasa Yosal Iriantara. Yogyakarta: Pustaka Pelajar

Azizah, A., Abraham, J., \& Dhowi, B. (2017). Pathway to Entrepreneurship University: an Autoethnography of Entrepreneurial Research Experience. Journal of Education and Learning, 11(3), 319-331.

Bachri Thalib, S. (2016). the effect of school supervisors competence and school principals compotence on work motivation and performance of junior high school teachers in maros regency, indonesia. International Journal Of Envirimental Dan Science Education, 11(15), 7310-7317.

Barken, R., Denton, M., Sayin, F. K., Brookman, C., Davies, S., \& Zeytinoglu, I. U. (2018). The influence of autonomy on personal support workers' job satisfaction, capacity to care, and intention to stay. Home health care services quarterly, 37(4), 294-312.

Benson, S. G., \& Dundis, S. P. (2003). Understanding and motivating health care employees: integrating Maslow's hierarchy of needs, training and technology. Journal of nursing management, 11(5), 315-320.

Bibi, P., Pangil, F., Johari, J., \& Ahmad, A. (2017). The Impact of Compensation and Promotional Opportunities on Employee Retention in Academic Institutions: The Moderating Role of Work Environment. International Journal of Economic Perspectives, 11(1), 1-15.

Biggs J \& Watkins, D. (1995). Classroom Learning: Educational Psychology for the Asian Teachers. Singapore: Prentice Hall.

Bouzenita, A. I., \& Boulanouar, A. W. (2016). Maslow's hierarchy of needs: An Islamic critique. Intellectual Discourse, 24(1), 1-17.

Carcolini, P. J. (2017). Curricula for Sustainability in Higher Education. [Book Review]. Journal of Ethnic and Cultural Studies, 4(2), 102-104.

Collins, M. (1990). Enrollment, recruitment, and retention of minority faculty and staff in institutions of higher education. Action in Teacher Education, 12(3), 57-63.

Dinh, H. (2019). Towards a Knowledge-rich Curriculum. Journal of Curriculum Studies Research, 1(1), 54-70. Retrieved from https://curriculumstudies.org/index.php/CS/article/view/6

Edgar, F \& Geare, A. (2005). HRM practice and employee attitudes: Different measuresDifferent results. Personnel Review, 34(5), 534-549. DOI: 10.1108/00483480510612503

Fomunyam, K. G. (2018). Deconstructing quality in South African higher education. Quality Assurance in Education, 26(1), 44-59. 
Gajić, J. (2012). Importance of marketing mix in higher education institutions. Singidunum journal of applied sciences, 9(1), 29-41.

Ginting, E., Manning, C., \& Taniguchi, K. (2018). Indonesia: Enhancing Productivity through Quality Jobs: Indonesia: Asian Development Bank.

Gora, A. A., Ștefan, S. C., Popa, Ș. C., \& Albu, C. F. (2019). Students' Perspective on quality assurance in higher education in the context of sustainability: A PLS-SEM approach. Sustainability, 11(17), 4793.

Graffam, J., Shinkfield, A. J., \& Hardcastle, L. (2008). The perceived employability of exprisoners and offenders. International journal of offender therapy and comparative criminology, 52(6), 673-685.

Grewal, I., Maher, A., Watters, H., Clemens, D., \& Webb, K. (2019). Rewriting Teacher Education: Food, Love, and Community. Journal of Culture and Values in Education, 2(3), 44-60. Retrieved from https://cultureandvalues.org/index.php/JCV/article/view/51

Hale, A. J., Ricotta, D. N., Freed, J., Smith, C. C., \& Huang, G. C. (2019). Adapting Maslow's hierarchy of needs as a framework for resident wellness. Teaching and learning in medicine, 31(1), 109-118.

Harvey, L. \& Green, D. (1993). "Defining quality," Assessment and Evaluation in Higher Evaluation, 18(1), 9-34.

Hatta, I. H., \& Rini, S. (2018). Developing Job Satisfaction which Support Improvement of Organizational Performance Private High Schools Located in Indonesia. International Journal of Engineering \& Technology, 7(3), 529-534.

Huiszoon, Paul; Martinent, Guillaume \& Bodet, Guillaume. (2018) Sport governing bodies' influence on non-transactional fan behaviours. Managing Sport and Leisure, 23(1-2), 123138, DOI: $10.1080 / 23750472.2018 .1502623$

Hyršlová, J., Tomšík, P., \& Vnoučková, L. (2017). Relation Between Sustainability-Related Communication and Competitiveness in the Chemical Industry. Acta Universitatis Agriculturae et Silviculturae Mendelianae Brunensis, 65(1), 283-292.

Jonas, J. (2016). Making practical use of Maslow's Hierarchy of Needs theory to motivate employees: a case of Masvingo Polytechnic. Journal of Management \& Administration, 2016(2), 105-117.

Juwitasari, R. (2019). The Japanese Legacy: What's Still Left in The Education System in Indonesia? Thammasat Review, 22(1), 64-76.

Kehrer, J. P., Kradjan, W., Beardsley, R., \& Zavod, R. (2008). New pharmacy faculty enculturation to facilitate the integration of pharmacy disciplines and faculty retention. American journal of pharmaceutical education, 72(1), 18.

Kezar, A. (2005). Redesigning for collaboration within higher education institutions: An exploration into the developmental process. Research in Higher Education, 46(7), 831860.

Krynski, A. (2019). In a State of Fragility: The Compromised Dignity of Communities, Indignation, and the Incapacitation of Public Education. Journal of Culture and Values in Education, 2(3), 1-24. Retrieved from https://cultureandvalues.org/index.php/JCV/article/view/52

Latip, M. S. A., May, R. Y. Y., Arif, M., Kadir, A., \& Kwan, T. C. (2019). Does Program fees Affect the Relationship between Lecturers' Competencies and Student'Satisfaction in the Digital Era? A Case of Malaysia Higher Education. International Journal Of Academic Research In Business And Social Sciences, 9(7). 
Leithwood, K., Harris, A., \& Hopkins, D. (2008). Seven strong claims about successful school leadership. School leadership and management, 28(1), 27-42.

Lenn, M.P. (2004). Quality assurance and accreditation in higher education in East Asia and the Pacific, Washington DC: The World Bank.

Lester, D. (2013). Measuring Maslow's hierarchy of needs. Psychological Reports, 113(1), 15-17. Mampane, P. (2012). The Teacher Turnover Crisis: Evidence from South Africa. Business Education \& Accreditation, 4(2), 73-83,

Mari Elken \& Bjørn Stensaker. (2018). Conceptualising 'quality work' in higher education, Quality in Higher Education, 24(3), 189-202. DOI: 10.1080/13538322.2018.1554782

Mbiti, I. M. (2016). The need for accountability in education in developing countries. Journal of Economic Perspectives, 30(3), 109-132.

Milman, A., \& Dickson, D. (2014). Employment characteristics and retention predictors among hourly employees in large US theme parks and attractions. International Journal of Contemporary Hospitality Management, 26(3), 447-469. https://doi.org/10.1108/IJCHM04-2013-0178

Moreira-Fontán, E., García-Señorán, M., Conde-Rodríguez, Á., \& González, A. (2019). Teachers' ICT-related self-efficacy, job resources, and positive emotions: Their structural relations with autonomous motivation and work engagement. Computers \& Education, 134, 63-77.

Nawaz, M.A., Afzal, N., \& Shehzadi, K. (2013). Problems of formally employed women: A case study of Bahawalnagar, Pakistan. Asian Journal of Empirical Research 3(10), 1291-1299.

NEA (National Education Association). (2006). School quality: Issues in education . (http;www.nea.org/jobs/). Diambil dari http://www.proquest.com/pqdweb.html

Nelis, D., Kotsou, I., Quoidbach, J., Hansenne, M., Weytens, F., Dupuis, P., \& Mikolajczak, M. (2011). Increasing emotional competence improves psychological and physical wellbeing, social relationships, and employability. Emotion, 11(2), 354.

Pasquier, F \& Nicolescu, B. (2019). To be or not to be transdisciplinary, That is the new question, So, How to be transdisciplinary? Transdisciplinary Journal of Engeneering and Sciences, 10, pp. 7-16. DOI: 110.22545/2019.0110.

Raziq, A., \& Maulabakhsh, R. (2015). Impact of working environment on job satisfaction. Procedia Economics and Finance, 23, 717-725.

Robbins, C., Bishop, J., \& Tarman, B. (2019). Against Reactionary Populism: Opening a Needed Conversation in Education. Journal of Culture and Values in Education, 2(3), i-vi. Retrieved from https://cultureandvalues.org/index.php/JCV/article/view/59

Sallis, E. (2002). Total quality management in education. London: Kogan Page Limited

Shah, M, Nair, Said \& Wilson, Mark. (2011). Quality Assurance in Australian Higher Education: Historical and Future Development. Asia Pacific Educ. Rev. 12:475-483. DOI: 10.1007/s 12.564-011-9152-2.

Shahrawat, A., \& Shahrawat, R. (2017). Application of maslow's hierarchy of needs in a historical context: case studies of four prominent figures. Psychology, 8(07), 939-947.

Siddique, A., Aslam, H. D., Khan, M., \& Fatima, U. (2011). Impact Of Academic Leadership On Faculty's Motivation And Organizationaleffectiveness In Higher Education System. International Journal of Academic Research, 3(3), 10-21.

Sinaga, O., Lis, M., \& Razimi, M. S. A. (2019). Education and core skills in the performance with mediating role of employee innovation. Polish Journal of Management Studies, 19.

Tadeu, P., Fernandez Batanero, J., \& Tarman, B. (2019). ICT in a Global World. Research in Social Sciences and Technology, 4(2), i-ii. Retrieved from https://ressat.org/index.php/ressat/article/view/431 
Tarman, B. (2017). Editorial: The Future of Social Sciences. Research in Social Sciences and Technology, 2(2). Retrieved from http://ressat.org/index.php/ressat/article/view/329

Tarman, B. (2016). Innovation and Education. Research in Social Sciences and Technology, 1(1). Retrieved from http://ressat.org/index.php/ressat/article/view/3

Volegzhanina, I. S., Chusovlyanova, S. V., Adolf, V. A., Bykadorova, E. S., \& Belova, E. N. (2017). Knowledge management as an approach to learning and instructing sector university students in post-soviet professional education. Journal of Social Studies Education Research, 8(2), 39-61.

Watty, K. (2006). Want to know about quality in higher education? Ask an academic. Quality in Higher Education, 12(3), 291-301.

World Bank. (2018). The World Bank Annual Report 2018 (English). Washington, D.C.: World Bank Group. http://documents.worldbank.org/curated/en/630671538158537244/TheWorld-Bank-Annual-Report-2018

Woofter, S. (2019). Book Review: Building Equity: Policies and Practices to Empower All Learners. American Journal of Qualitative Research, 3(1), 136139. https://doi.org/10.29333/ajqr/5815

Woya, A. A. (2019). Employability among Statistics Graduates: Graduates' Attributes, Competence, and Quality of Education. Education Research International,7(1), 1-7.

Zafar, J. (2015). The mediating effect of perceived employability on the relationship between protean career orientation, affective commitment and subjective career success among academics in Pakistan. Malaysia: Universiti Utara Malaysia.

\section{Notes on Contributors}

Prof. Dr. Teguh Budiharso is a senior lecturer in English Language Education, Faculty of Culture and Language, State Islamic Institute (IAIN) of Surakarta, Indonesia. He holds a doctorate degree in English Language Education from Malang State University. He teaches language curriculum and pedagogy, TEFL, academic writing, language testing and assessment, English for Academic Purposes (EAP), and research methods in language teaching. His current research interests are teacher education issues, teacher professional development issues, multicultural education, EAP, academic writing and curriculum \& pedagogy.

Assoc. Prof. Bulent Tarman has more than 25 years of professional experience in the field of education. He earned his Ph.D. degree in Curriculum \& Instruction (social studies education), as well as a minor in Comparative and International Education at the Penn State University. He also holds a BA in history at Hacettepe University and MEd. in social studies education at University of Missouri, Columbia. His research interests include, Social Studies Education; Teacher Education; Innovation in Education; Citizenship and Human Rights Education, Globalizing Education, Curriculum Development; Gender Issues in Education; ICT in Education; and Multiculturalism in Education. 